the "flight" they reported that the patient withstood the lowered oxygen tension better than both individuals with the sickle-cell trait and normal control subjects.

Findlay, Boulter, and MacGibbon (1947) demonstrated invivo sickling in three sickle-cell trait carriers flying at $15,000 \mathrm{ft}$ $(4,570 \mathrm{~m})$ and they advised that oxygen should be carried in all aeroplanes in which Africans are passengers. The sickle-cell trait is no longer an important risk in most commercial flights, but if, as on certain African routes, a Negro traveller must take an unpressurized aircraft it would be wise to ascertain the sickling status before departure. Under these exceptional circumstances even the relatively benign sickle-cell trait carrier should seek surface transport, unless at over $7,000 \mathrm{ft}(2,135 \mathrm{~m})$ oxygen can be continuously administered.

Patients with sickle-cell haemoglobin $\mathrm{C}$ disease seem to be at greatest risk and they should if possible completely avoid air travel. While continuous oxygen therapy could be made available in exceptional circumstances, it is not feasible as a normal commercial practice.

However, cases may be so benign as to be unsuspected until an in-flight incident occurs. The only way to avoid this situation would be to set up a screening system available to all Negro travellers, which would detect not only the presence of sickle haemoglobin but specifically cases of undiagnosed sickle-cell haemoglobin $\mathrm{C}$ disease, sickle-cell thalassaemia, and the unusual clinically benign cases of sickle-cell anaemia with persistent splenomegaly. The classical case of sickle-cell anaemia will almost certainly be already diagnosed. While air travel, even in pressurized aircraft, cannot be recommended for these latter patients it would seem that the risk of infarction in flight is surprisingly small.

\section{AIRCREW FITNESS}

Finally, though the foregoing reports relate to problems for airline passengers the question of sickle-cell disease and aircrew fitness needs careful consideration. Clearly, patients with the more severe sickle-cell disorders, including sickle-cell haemoglobin $\mathrm{C}$ disease, should not be allowed to fly as aircrew, and this attitude seems to be generally accepted. There is currently less agreement on the suitability for aircrew duties of sickle-cell trait carriers. Lewis (1970) suggested that such patients should not enter a career involving airline flying, but that those aircrew already trained who are subsequently found to have the sicklecell trait should be allowed to continue flying under medical supervision.

There seems to be little logic in this argument, which presumably advocates rejection of new entrants with the sickle-cell trait on the grounds that they may represent a safety risk. To retain those already trained, though superficially humane, seems to ignore this implied risk, and it is difficult to reconcile the two attitudes. It would seem most important that some firm, lasting, and internationally acceptable policy be defined on this subject by the authorities responsible for aircrew licensing.

We are grateful to Dr. G. Blanshard, Dr. R. P. Britt, and Wing Commander F. E. S. Keiller for permission to report cases under their care.

\section{References}

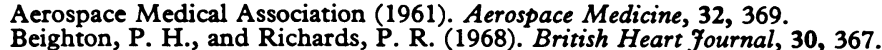
Canby, C. B., Carpenter, G., and Ellmore, L. F. (1944). Archives of Surgery, Canby, C. B.

Coleman, W. A., and Furth, F. W. (1956). Archives of Internal Medicine, 98, 247 .

Cooley, J. C., Peterson, W. L., Engel, C. E., and Jernigan, J. P. (1954). Fournal of the American Medical Association, 154, 111.

Diggs, L. W. (1965). American fournal of Clinical Pathology, 44, 1.

Doenges, J. P., Smith, E. W., Wise, S. P., and Breitenbucher, R. B. (1954). fournal of the American Medical Association, 156, 955.

Erlandson, M. E., Schulman, I., and Smith, C. H. (1960). Pediatrics, 25, 629.

Findlay, G. M., Boulter, E. A., and MacGibbon, C. B. (1947). Fournal of the Royal Army Medical Corps, 89, 138.

Henderson, A. B., and Thornell, H. E. (1946). Fournal of Laboratory and Clinical Medicine, 31, 769.

Jones, S. R., Binder, R. A., and Donowho, E. M. (1970). New England fournal of Medicine, 282, 323.

Konotey Ahulu, F. I. D. (1969). Lancet, 1, 267.

Lewis. R. A. (1970). Sickle States: Clinical Features in West Africans. Accra, Ghana Universities Press.

McCormick, W. F. (1961). American fournal of the Medical Sciences, 241, 329. Motter, R., Luttgens, W. F., Peterson, W. C., Stock, A. E., and Motulsky,

A. G. (1956). Annals of Internal Medicine, 44, 257.
Serjeant, G. R. (1970a). West Indian Medical fournal, 19, 1.

Serjeant, G. R. (1970b). British Fournal of Haematology, 19, 635.

Sluijter, M. E. (1969). In Recent Advances in Aerospace Medicine, ed. D. E. Busby. Dordrecht, the Netherlands, Reidel.

Smith, E. W., and Conley, C. L. (1955). Bulletin of the Fohns Hopkins Hospital, 96, 35 .

Sullivan, B. H. (1950). Annals of Internal Medicine, 32, 338.

Thompson, G. R. (1963). British Medical fournal, 2, 976.

\title{
Transrectal Prostatic Biopsy
}

\author{
W. F. HENDRY, J. P. WILLIAMS
}

British Medical fournal, 1971, 4, 595-597

\section{Introduction}

\section{Summary}

Transrectal prostatic biopsy specimens were taken from 218 patients with prostatic symptoms-138 by the Franzen aspiration technique without anaesthesia as outpatients and 80 by the Silverman technique under general anaesthesia. A reliable diagnosis was obtained in $82 \%$ of the former and $95 \%$ of the latter.

St. Peter's Hospitals and Institute of Urology, London W.C.2 W. F. HENDRY, CH.M., F.R.C.S., Senior Surgical Registrar J. P. WILLIAMS, M.CHIR., F.R.C.s., Senior Lecturer
It is generally agreed that the diagnosis of carcinoma of the prostate should be confirmed microscopically before treatment is started. Though an extensive transurethral prostatectomy will nearly always confirm the diagnosis (Denton et al., 1967), there is good evidence that a specimen taken for biopsy by needle is more reliable than a linnited specimen obtained via the urethra (Purser et al., 1967). Estimates of the accuracy of needle biopsy, however, have ranged from 50 to $90 \%$ (Kaufman et al., 1954) up to 95\% (Rinker and Shuman, 1952; Bianchi, 1956).

While the perineal route has usually been used for taking tissue from the prostate by needle, Astraldi (1937) first described good results with the transrectal approach, and noted minimal morbidity in a series of more than 100 cases. The safety and efficiency of this approach has since been confirmed by Grabstald and Elliott (1953), Grabstald (1954, 1956), Graham (1958), and Daves et al. (1961). 
Various needles have been used to provide material for cytological or histological diagnosis. Ferguson (1930) aspirated prostatic material for cytological examination by means of a fine needle inserted via the perineum. Franzen et al. (1960) developed a fine needle and guide for transrectal use, and satisfactory results with this technique have been confirmed by Williams et al. (1967). The needle designed by Silverman (1938) was first used for taking prostatic tissue for biopsy by Peirson and Nickerson (1943), who obtained satisfactory histological specimens in $86 \%$ of 36 cases.

In this study the merits of the Franzen and Silverman techniques are compared.

\section{Franzen Needle Technique}

Transrectal aspiration of prostatic tissue was carried out in 138 patients by means of the fine needle and guide (see Fig.) designed by Franzen et al. (1960). Early experience showed

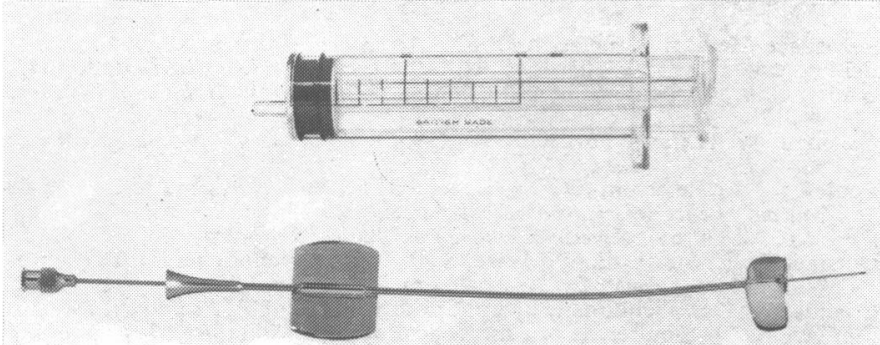

Franzen needle and guide; the Gillette Scmitar plastic disposable syringe has provec satisfactory for aspiration.

that a Gillette Scimitar 10-ml or 20-ml disposable plastic syringe was as effective as the original specially designed aspirating syringe; other disposable syringes proved less satisfactory. No anaesthetic was used in these outpatients, all of whom tolerated the examination well.

The procedure was carried out with the patient in the left lateral position, up to four separate aspirations being performed. An account of this technique with details of the interpretation of smears has been published (Williams et al., 1967). The criteria of malignancy were those described by Mason (1966).

In order to establish the method in our hands, 21 cases of benign prostatic hypertrophy were investigated in this way before undergoing surgery. Six patients in the overall series were diagnosed on clinical grounds as having prostatitis. The remainder were, placed in the "clinically suspicious" and "clinically certain" categories of malignancy. The latter group included cases with hard craggy prostates on rectal examination, patients with characteristic bone deposits, and those with a sustained rise in the serum acid phosphatase. Some of these patients underwent transurethral resection, thus providing additional histological confirmation of the diagnosis. In the former group histological confirmation of the diagnosis was obtained less often; however, a positive diagnosis on Franzen aspiration led to hormone therapy which produced a diminution in obstructive symptoms in all cases.

TABLE I-Results in Franzen Needle Aspiration Specimens of Prostate in 138 Patients Related to Clinical Diagnosis

\begin{tabular}{|c|c|c|c|c|c|c|c|}
\hline \multirow[b]{2}{*}{$\underset{\text { Diagnosis }}{\text { Clinical }}$} & \multirow[b]{2}{*}{ No. } & \multicolumn{5}{|c|}{ Diagnosis } & \multirow[b]{2}{*}{$\begin{array}{c}\text { Wrong } \\
\text { Diagnosis }\end{array}$} \\
\hline & & $\begin{array}{c}\text { Unsatis- } \\
\text { factory } \\
\text { Preparation }\end{array}$ & Benign & $\begin{array}{c}\text { Prosta- } \\
\text { titis }\end{array}$ & $\begin{array}{l}\text { Suspi- } \\
\text { cious }\end{array}$ & $\begin{array}{c}\text { Malig- } \\
\text { nant }\end{array}$ & \\
\hline $\begin{array}{l}\text { Benign } \\
\text { Prostatitis } \\
\text { Suspicious } \\
\text { Malignant }\end{array}$ & $\begin{array}{r}21 \\
6 \\
37 \\
74\end{array}$ & $\frac{-}{3^{*}}$ & $\begin{array}{c}20 \\
19+ \\
5\end{array}$ & $\begin{array}{l}-6 \\
1 \\
\end{array}$ & $\begin{array}{c}\overline{7} \\
7 \\
7\end{array}$ & $\begin{array}{r}1 \\
7 \\
49\end{array}$ & $\begin{array}{l}\frac{1}{3} \\
5\end{array}$ \\
\hline Total & 138 & $16(11.6 \%)$ & 44 & 7 & 14 & 57 & $9(6.5 \%)$ \\
\hline
\end{tabular}

* One proved malignant.

tTwo proved malignant.
The results are summarized in Table I. In just over $10 \%$ of the cases unsatisfactory material was aspirated, even on repeated attempts; errors in diagnosis were made on nine occasions $(6.5 \%)$. Thus a reliable diagnosis was made in $82 \%$ of the cases. There were no significant complications.

\section{Silverman Needle Technique}

During 1968 to 197080 specimens obtained by the transrectal route were examined at St. Mary's General Hospital, Portsmouth. After bimanual examination of the prostate under general anaesthesia, with the patient in the lithotomy position, specimens were taken from glands that were suspected of malignancy, the Franklin modification of the Silverman needle being used; generally, three cores were taken, two from the more suspicious side. These specimens were immediately fixed in buffered neutral formalin and sections were prepared and stained with haematoxylin and eosin. The results are summarized in Table II, from which it may be seen that satisfactory material for examina-

TABLE II-Results in Specimens of Prostate Taken by Silverman Needle in 80 Patients Related to Clinical Diagnosis

\begin{tabular}{|c|c|c|c|c|c|c|}
\hline \multirow{2}{*}{$\underset{\text { Diagnosis }}{\text { Clinical }}$} & \multirow{2}{*}{ No. } & \multicolumn{4}{|c|}{ Diagnosis } & \multirow{2}{*}{$\begin{array}{c}\text { Wrong } \\
\text { Diagnosis }\end{array}$} \\
\hline & & Benign & Dubious & Malignant & Other & \\
\hline $\begin{array}{l}\text { Benign } \\
\text { Suspicious } \\
\text { Malignant }\end{array}$ & $\begin{array}{r}1 \\
23 \\
56\end{array}$ & $\begin{array}{c}1 \\
11^{*} \\
2 \dagger\end{array}$ & $\underline{-1}$ & $\begin{array}{r}-9 \\
54\end{array}$ & $\overline{2 f}$ & $\overline{\frac{1}{2}}$ \\
\hline Total & 80 & 14 & 1 & 63 & 2 & $3(4 \%)$ \\
\hline
\end{tabular}

* One proved malignant.

†Both proved malignant

$\ddagger$ One case carcinoma of bladder, one case tuberculosis.

tion was obtained in all cases except one, though the procedure had to be repeated in three cases to give a positive result when the histological diagnosis seemed to be at variance with the clinical impression. The histological diagnosis was subsequently shown by prostatectomy to be wrong in three cases. Thus a reliable diagnosis was made in $95 \%$ of cases.

Serious complications did not occur after this procedure. In eight patients the urine changed from bacteriologically sterile to infected; however, since all these patients had indwelling catheters, the significance of this finding is uncertain. In 55 patients who were examined per rectum after intervals of 3 to 24 months there was no evidence of tumour tracking along the needle path.

\section{Discussion}

In order to establish the diagnosis of carcinoma of the prostate effectively the procedure for obtaining material for biopsy should be simple, safe, and accurate.

The Franzen aspiration technique offers distinct advantages to the patient. The fine needle causes minimal discomfort, and is used on outpatients without anaesthesia; in addition, the risks are minimal-Esposti (1966) recorded 1,430 aspirations in 1,110 patients without significant complications. In contrast, Wendel and Evans (1967) recorded a complication rate of $7 \%$ in 250 patients after using the Silverman needle by the perineal or transrectal route. Davison and Malament (1971) described a high incidence of positive urine cultures and febrile reactions after transrectal use of the Silverman needle, and they recommend routine antibiotic cover. However, no serious infective complications were observed in our patients.

Several studies have compared the accuracy of the Franzen technique, which gives a cytological diagnosis, with results obtained with needles of larger bore inserted via the perineum and providing histological material. Andersson et al. (1967) 
noted that the chances of obtaining adequate specimens were better when they were taken by a surgeon well versed in the method, and concluded that in experienced hands the chances of obtaining representative material were probably equal irrespective of the type of instrument used. Ekman et al. (1967) also found little difference in the rate of positive findings and concluded that the Franzen technique was preferable since it was gentler and less inconvenient to the patient. Similarly, Alfthan et al. (1968) concluded that the diagnostic reliability of cytological samples obtained by a thin needle was as good as in histological samples obtained by a transperineal Silverman needle. In contrast, our results suggest that multiple cores of prostate removed by the transrectal route under general anaesthesia with the Silverman needle are more likely to provide a positive result than aspiration of a small amount of material without anaesthetic by the Franzen technique. However, the latter possesses advantages in safety and convenience to the patient.

We therefore suggest that the Franzen technique be used initially as an outpatient procedure when the patient first attends; should the result prove unexpectedly negative, it can easily be repeated. However, should the second attempt prove unsatisfactory, or should the patient require a general anaesthetic for other reasons, such as for cystoscopy, the Silverman technique should then be used, as it is more likely to produce a positive specimen. Whichever method is used, we conclude that the transrectal approach is simple and accurate for the surgeon and safe for the patient.

We wish to thank Mr. J. D. Fergusson, of the St. Peter's Hospitals, and Mr. W. W. Wiggins-Davies and Mr. John Vinni- combe, of St. Mary's General Hospital, Portsmouth, for permission to study patients under their care; also Dr. R. C. B. Pugh for the Franzen studies and Dr. R. D. Clay and Dr. John Burston for interpreting the Silverman preparations.

\section{References}

Alfthan, O., Klintrup, H. E., Koivuniemi, A., and Taskinen, E. (1968). Duodecim, 84, 506

Andersson, L., Jonsson, G., and Brunk, U. (1967). Scandinavian fournal of Urology and Nephrology, 1, 227.

Astraldi, A. (1937). Urologic and Cutaneous Review, 41, 421.

Bianchi, F. (1956). Fournal of Urology, 76, 645.

Daves, J. A., Tomskey, G. C., and Cohen, A. E. (1961). fournal of Urology, 85,180 .

Davison, P., and Malament, M. (1971). Fournal of Urology, 105, 545.

Denton, S. E., Valk, W. L., Jacobson, J. M., and Kettunen, R. C. (1967). Fournal of Urology, 97, 127.

Ekman, H., Hedberg, K., and Persson, P. S. (1967). British fournal of Urology, 39, 544

Esposti, P. L. (1966). Acta Cytologica, 10, 182

Ferguson, R. S. (1930). American fournal of Surgery, 9, 507.

Franzen, S., Giertz, G., and Zajicek, J. (1960). British Fournal of Urology, 32, 193.

Grabstald, H. (1954). Fournal of Urology, 74, 211.

Grabstald, H. (1956). British fournal of Urology, 28, 176.

Grabstald, H., and Elliott, J. L. (1953). Fournal of the American Medical Association, 153, 563 .

Graham, W. H. (1958). British Fournal of Urology, 30, 389.

Kaufman, J. J., Rosenthal, M., and Goodwin, W. E. (1954). Fournal of Urology, 72, 450

Mason, M. K. (1960). In Cytological Diagnosis in Medical Practice, ed. J. Bamforth. London, Churchill.

Peirson, E. L., and Nickerson, D. A. (1943). New England fournal of Medicine, 228,675 .

Purser, B. N., Robinson, B. C., and Mostofi, F. K. (1967). Fournal of Urology, 98, 224

Rinker, J. R., and Shuman, W. G. (1952). Fournal of Urology, 67, 709.

Rinker, J. R., and Shuman, W. G. (1952). Gournal of Urology,

Wendel, R. G., and Evans, A. T. (1967). Fournal of Urology, 97, 122.

Williams, J. P., Still, B. M., and Pugh, R. C. B. (1967). British fournal of Urology, 39, 549 .

\section{PRELIMINARY COMMUNICATIONS}

\section{Detection of Hepatitis Associated Antigen by the Latex Agglutination Test}

\section{J. M. LEACH, B. J. RUCK}

British Medical fournal, 1971, 4, 597-598

\section{Summary}

Hepatitis associated antigen may be detected quickly and reliably by the latex agglutination test, using antiserum from guinea pigs immunized with the antigen. The latex test has a sensitivity comparable to the counter current immunoelectrophoresis technique.

The discovery by Blumberg et al. (1967) of the Australia antigen (hepatitis associated antigen-HAA) has been followed by the development of a number of tests for the presence of this agent in blood. For routine work the most commonly used tests are gel diffusion in Ouchterlony plates, counter current immunoelectrophoresis, and complement fixation. Each of these tests has its merits and disadvantages for screening of large numbers of blood samples.

Pfizer Limited, Sandwich, Kent

J. M. LEACH, M.A., Project Leader in Research Division

B. J. RUCK, M.I.BIOL., Senior Technician
The gel diffusion test is simple to perform and is economical in the use of detector antiserum but is not very sensitive and the results are not available for at least 24 hours. It is useful, however, in being readily adapted to making comparisons of antigenic identity. Counter current immunoelectrophoresis is more sensitive than gel diffusion and gives a definitive result in about two hours. This technique has the additional advantage of allowing the simultaneous demonstration of antigen and antibody in the test sample. It is, however, more extravagant in the use of antiserum than gel diffusion and there is an appreciable expense in the preparation or purchase of agarose films and ancillary equipment. The complement fixation test is the most sensitive of these three tests but it is more tedious to perform, is invalidated by anticomplementary sera, consumes very much more antiserum than the tests based on the precipitin reaction, and the results are not available for 24 hours (Blumberg et al., 1970).

\section{Latex Agglutination Test}

It was felt that a need existed for a rapid test with a sensitivity comparable to the complement fixation test which could be performed without elaborate equipment, and for this reason it was decided to investigate the possibility of using a latex agglutination technique. The latex agglutination test has become accepted for the detection of the rheumatoid arthritis factor (Singer and Plotz, 1956) and is widely used as a test for human chorionic gonadotrophin in the urine of pregnant women (Graham and Kalish, 1967). Our experience shows that it is equally suited to the detection of HAA in human serum and plasma. 